\title{
DESIGN AND DISCOURSE OF MODERN STANDARD ARABIC E-TEXTBOOK
}

\author{
Muhammad Thohir, Mohammad Kurjum, dan Abdul Muhid \\ UIN Sunan Ampel Surabaya, Surabaya \\ e-mail: muhammadthohir@uinsby.ac.id
}

\begin{abstract}
An E-textbook of Modern Standard Arabic (MSA) is an important device that supports the on-line practical aspects of the teaching Arabic as a foreign language (TAFL). The present study was aimed at describing the characteristics of the design and discourse of the Schulz's E-textbooks of MSA. The study focused on Schulz MSA E-Textbook as an instructional material package of standard Arabic of the intermediate levels (B1 and B2 levels). The study used the qualitative research approach with the discourse-analysis method of data analyses.The results showed the following findings. The design of the $E$-package is web-based with multimedia as resources. The content prioritizes on grammar material in each initial lesson unit of the textbook. Although standard modern Arabic is used as the language variant for the language skills, colloquial language variants are given sufficient attention that can be accessed only in the E-edition version of the package. In terms of the contents of the discourse, a wide selection of texts are used with varied themes in the field of education, social affairs, economy, culture, politics, religion, environment, and technology. Citations embedded in header texts do not always match the contents of the discourse. The religious discourse pieces in the materials seem to be positioned more as socio-cultural facts rather than as theological facts.
\end{abstract}

Keywords: E-textbook, Modern Standard Arabic, discourse, learning material

\section{DESAIN DAN WACANA BUKU PELAJARAN BAHASA ARAB BAKU}

\begin{abstract}
Abstrak
Buku ajar elektronik bahasa Arab standar merupakan perangkat penting yang mendukung aspek-aspek praktis online pada pembelajaran bahasa Arab sebagai bahasa asing (PBABA). Penelitian ini bertujuan untuk menggambarkan karakteristik desain dan muatan wacana buku ajar elektronik bahasa Arab Standar. Kajian difokuskan pada e-text karya Eckehard Schulz yang banyak digunakan di Indonesia dan dibatasi pada tingkat menengah (tingkat B1-B2). Penelitian menggunakan pendekatan penelitian deskriptif kualitatif dengan analisis wacana. Hasil penelitian menunjukkan temuan berikut. Desain e-textbook MSA Schulz berkarakter web based dengan multimedia sebagai resources. Kontennya memprioritaskan materi tata bahasa di setiap awal pelajaran. Meskipun keterampilan berbahasa Arab ditekankan pada penggunaan variasi standar atau modern
\end{abstract}


language, variasi colloquial language mendapat perhatian cukup memadai yang hanya dapat diakses dalam versi e-edition. Dari segi muatan wacana, ia menghadirkan banyak muatan seperti pendidikan, sosial, ekonomi, budaya, politik, agama, lingkungan, dan teknologi. Kutipan yang disematkan di setiap header halaman tidak selalu cocok dengan isi wacana. Yang menarik, wacana agama di dalamnya terlihat lebih diposisikan sebagai fakta sosial-budaya daripada fakta teologis.

Kata kunci: buku elektronik, bahasa Arab standar, wacana, kegiatan pembelajaran

\section{INTRODUCTION}

Arabic is learned in three variants: classical written Arabic (CWA), modern standard Arabic (MSA), and spoken Arabic (SA). CWA is one that is used in the al-Quran and literature. MSA, acknowledged as standard variety often called fuşh $\bar{a}$, is that which consists of the introduction of vocabulary in formal contexts (Abdelali, 2004: 23). MSA is used by 22 country members of UNESCO, 422 million Arabs, and 1.5 billion Islamic followers in the world. In this state, the learning of Arabic as a foreign language (LAFL) has spread to a wide area in the world.

In coherence with the strategic issues of the 4.0 industrial revolution, LAFL has developed in various programs and designs, formally and informally alike. Arabic has existed not only as a representation of the Arabic socio-cultural life, but also as part of the cyber-based dynamics of informational technology. One example is shown by the MSA program designed on-line by Eckehard Schulz, a professor in Arabic of the Leipziq University of Germany. This program is aimed at developing Arabic skills and competences internationally.
In Indonesia, this program has been established since 2016 by the Islamic State University (ISU) of Sunan Ampel as a language-learning project under the direct license of the Schulz program. Participants are 5,000 candidates of scholarship recipients who will pursue continuing education in various universities in the Middle-East countries. In the learning activities, participants are given access, by way of their own accounts, to on-line and classical face-toface instructional programs. Participants are given language-competence certificates, in accordance with their competence levels, directly by Leipziq University after taking the on-line test.

The present study that looks into the strategic issues on the MSA electronic learning materials is based on the premise that instructional packages are not only concerned with the strategies of teaching, but also with topics and ideas (Behnke, 2018). Instructional materials have even been regarded as a determining mediator for instructional processes (Schuh, Russell, \& Horne, 2018). The studies by Pepin, Gueudet, \& Trouche (2013) have emphasized that the interfaces of electronic instructional packages become 
a crucial element, including even the presentation of the instructional material.

Richards (2015: 92) mentions five principles of decent foreign-language teaching designs, namely: objectives, syllabus, structural format, and exercises. Here, the instructional objectives are placed in the front for the reasons that objectives will have impacts on the other components. Instructional objectives will show the nature of the language competences to be achieved. A language competency is understood by Fairclough (2003:82) as the ability to perform the knowledge and skills in a new situation; thus requiring the technological orientation of the discourse which is different from the traditional language.

Research on MSA has been conducted by Diab, Hacioglu, \& Jurafsky (2007: 177). They tried to adapt the support vector machine (SVM) of an English text into an MSA text, specifically in solving the problems of clitical tokenization on the morphological level. While this study is based on texts, the one by DrouaHamdani, et.al., (2012) is based on sounds. By using automatic speech recognition (ASR) for MSA speakers, they found that the ASR remains influenced by the local accents of the speakers. Internet-based research, such as one conducted by Nassiri, Lakhouaja, \& Cavalli-Sforza (2018), measures readability of MSA texts using the Tashkeela application while another by Aljasser \& Vitevitch (2018) describes the development of web-based interfaces to calculate the phonotactic probability in MSA. Meanwhile, Loukam, Hammouche, Mezzoudj, \& Belkredim
(2019) study how the association rule model extracts unique phrases from an MSA text.

In a study specifically related to a Schulz MSA learning program, Jaeni (2015) finds that his instructional book contains adequate ideologies and cultures of Arabic since it provides an appropriate portion of Islamic religious teachings by citing Quran and Hadist verses in each page. In terms of language skill contents, the study by Taufikurrahman (2015) finds that the Schulz package has contained the four language skills in a brief time and with recent topics and materials. This finding is strengthened by Ediyani's study (2016) stating that the package makes good Arabic learning although it lacks pictures in the book. In the same way, Masyhud (2017), who emphasizes more on the presentation of dialects, states that the Shulz MSA material is effective in improving pronunciation.

The foregoing discussion shows how there remain many possibilities in the Schluz MSA materials that have not received attention from researchers. A discourse analysis on an instructional material has not certainly given a complete picture if the discussion is mainly based on whether or not the materials are adequate as revealed by Jeni. As comparison, Purwanta (2013: 439) finds how historical texts show imbalance in that they are Javacentric with the consequence of lacks of non-native aspects. If Faruqi (2007) and Roibin (2010: 7) regard those religious texts do not necessarily represent the religion as a discourse, then Jeni's study still leaves questions of how Schulz MSA instructional 
materials present discourses as important materials of LAFL. The study by Pransiska (2018) about the MSA book in terms of design, construction, and implementation has not answered the questions either.

It is by those reasons that the present study is aimed more at giving a description of the nature Schulsz MSA elektronic instructional package: how to present various language instructional materials of standard Arabic. The study is arranged in two foci of discussion: what is the design of the electronic book like and how texts are presented in the book.

\section{METHOD}

The present study was descriptive qualitative research. The research subject was the MSA E-textbook Schulz (2017), professor of Arabic at Lepziq University of Germany. Narration of the book was presented in seven language (multilingual); however, only the Indonesian-Arabic version was used in this study. The research material was MSA Schulz E-textbook of the B level (intermediate), consisting of the two editions (B1 and B2). The electronic edition ( $E$-edition) was chosen for the reason that, though the contents were the same, E-edition was considered as more complete. In addition, in the E-editon, lessons 1 through 24 were presented in one menu selection while, in the interactive edition, these were presented in two books: lessons 1 to 12 in Book 1 and lessons 13 to 24 in Book 2.

The original version of the MSA $E$-textbook published in Germany was titled Modernes Hocharabisch Mit Einer Einführung In Hauptdialekte, Hamouda Edition, Leipziq: Germany. The
Indonesian-Arabic edition was printed in Leipziq in 2016, translated by a team from Maliki ISU of Malang consisting of Bahkruddin Fannani, Uril Bahruddin, Miftahul Huda, Zakiyah Arifa, Dewi Chamida, Ghufron Hanbali, and Makhi Ulil Kirom. The MSA Schulz E-textbook was designed for learners to obtain a competence certificate basedf on the Common European Framework of Reference for Languages (CEFR), and not the American Council of Teaching Foreign Languages (ACTFL).

This research material was accessible on https://modern-standard-arabic.net/. Data were collected from the $E$-textbook, both text based and graphical user-based, by way of reading and note-taking. Reading was done carefully and accurately; while note taking was done by writing down the data description, copying selected materials, making conclusions, and transcribing the materials using the determined categories. As a qualitative study, the primary instrument was the researcher who had a registered account in the MSA site. Data were analyzed using descriptivequalitative analyses, descriptive statistics, and discourse analyses.

\section{FINDINGS AND DISCUSSION \\ Findings \\ Design}

The Schulz MSA E-textbook can be described in three main frames: format, resourses, and contents and visual graphics. In the case of the format, the book consists of two forms: manual (paper textbook) and $E$-edition (E-textbook). For the $E$-edition, the material is accessible by 
pre-paying, not open online book (OOB); however, users are given a trial menu. The $E$-textbook is not a sofware application, not it it a digital text of the PDF or EPUB format. On the contrary, it is an internetbased online program that can be accessed on the computer or mobile devices using various platforms such as Windows, IOS, or Android.

In the case of resourses, Schulz MSA e-textbook is multi-media. Media for audio resources, for example, word pronunciation (examples and exercises), dialect sounds, and response sounds such as [huu] for wrong answers and applauses for correct answers. Not all exercises use this resource; only the ones with correct/ wrong responses. For the visual resources, texts are used, although not all. For the audiovisual resources, not all lessons provide one. For example, in Lesson 8, page 179 , it is written the way to use numbers 11 and 12 in Arabic. In its description, number 12 that is underlined has a lifelink to Youtube coded $v=V E U_{-}$ $g d v K h k w$. This humour video clip tells how to use teen numbers in Arabic that happens between two persons trapped in a lift as can be seen in Figure 1.

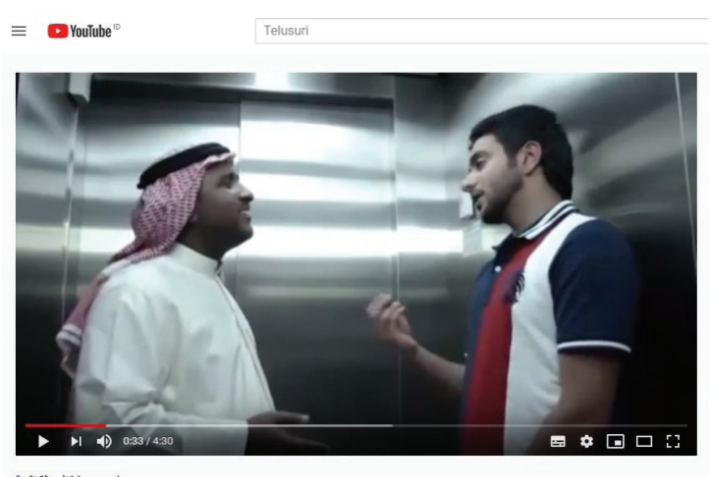

Figure 1. Video resource in Schulz MSA E-textbook
In the case of contents, the Schulz $E$-textbook is constructed of forewords, table of contents, directions for use, lists of abbreviations and transliterations, lessons 1 to 24 , intensive exercises for each lesson, and E-test. The material also provides sentence patterns in Arabic, sentence patterns in Indonesian, glossary (ArabicIndonesian), glossary (Indonesian-Arabic), numbers and figures, and list of verbs and conjugation. In the 24 lessons of this material, tag-lined as New ways to proficiency in Arabic, practical grammatical structures occupy the first presentation phase followed by list of high-frequency words, practice in intensive reading, introduction to dialects, introduction to discourse texts in various communicative events.

In the introduction to dialects, four main dialects popular in the Arabic world are selected: (1) Syria, including Lebanon and Palestine, (2) Morocco, (3) Iraq, including the Arab Gulfs, and (4) Egypt. Explanation of these four dialects is given at the end of the reading text. Meanwhile, in the form of analysis exercises, each lesson has different emphases but the total portion comes to the same percentage. Each dialect receives a portion of $25 \%$ in a total of 20 exercises of dialect introduction, as can be seen in Figure 2.

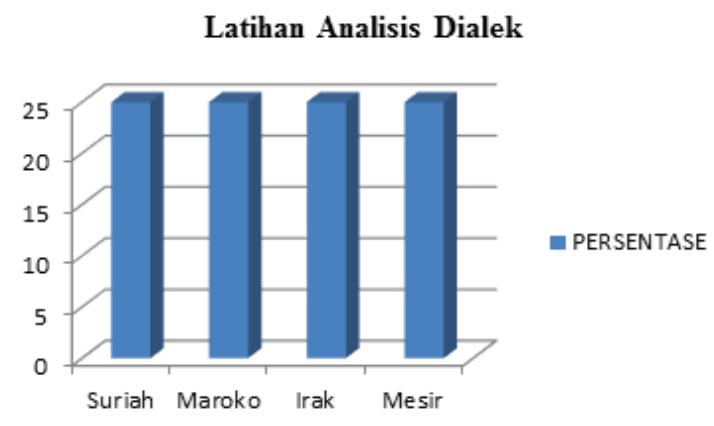

Figure 2. Percentages in emphases of dialect exercises 
Each lesson is scheduled for 8 to 12 hours depending on class conditions. pelajaran yang dapat dikondisikan sesuai keadaan kelas. On the first page of each lesson, the sequence of the exercises is given, not in a chronological order to suit the time allotment. For example, in Lesson 4, Hour 3, exercises 3 and 23 are recommended for class activities while exercises 2, 33, and 40 for homework assignments.

In the case of visual graphics, the book presents interfaces that are adequate to support learning. Other than texts, symbols in blue colours are used such as: $\nabla=$ writing, $($ i) $=$ listening comprehension, $\square=$ home assignment, $\square=$ computer work, and $\Theta_{\text {. }}$ practice (from ... to ...). These symbols contain files and audios which can be activated as a graphical userbased interface in the E-Edition version. For special grammar rules, examples and exercises are completed with red marking. This is expected to make it easy for the user to spot grammatical changes in the examples.

\section{Discourse}

The texts used in the material are based on Van Dijk macro discourse model, emphasizing the theme and topic of the passage whereby texts are considered part of a wider social context. Through discourse, an ideology is obtained, confirmed, changed, and abstracted by way of a text (Van Dijk, 2006). In this case, the variants of text contents become important data for the study since variants indicate the richness of text analyses. Text contents show the material variant that is written or spoken by the language user. Meanwhile, text content data are taken from the header texts and reading texts in the book. In accordance with the themes, the texts in the Schulz MSA material can be classified into: education, social, economy, culture, politics, religion, environment, and technology (Figure 3).

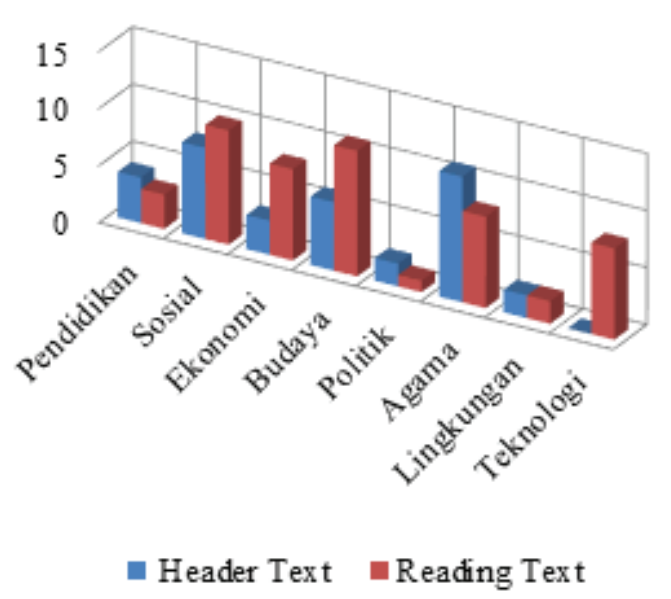

Figure 3. Themes of header texts and reading texts

Figure 3 shows that Schulz MSA material represents thematic varieties. For example, the header text in Lesson 17, "al-kitab khayru jâlisin (The book as the best friend)" classifies into educational, social, and cultural themes altogether. Meanwhile, in the reading text in Lesson 12, "Târîkh al-Ţib inda al-Arab wal Muslimin (History of Medicine for the Arabs and Moslems)," classifies into social, religious, and technological themes. 


\section{Header Test \& Reading Text}

Header Test \& Reading Text

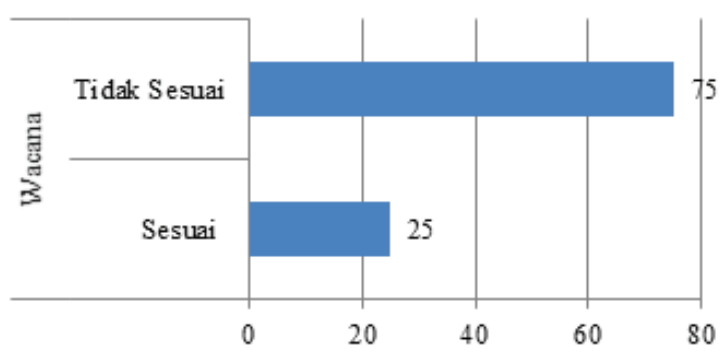

Figure 4. Comparison of text agreement between header texts and reading texts

Nevertheless, in consideration of the quantities, there is no match in numbers between the header texts and reading texts. Meanwhile, in terms of the themes, there is a high discrepancy between the two text types as it can be seen in Figure 4. Specifically, in relation to sentences cited on the header pages, the highest frequency is that which is religious taken from the Alquran and Hadits (Figure 3).

\section{Discussion}

$E$-textbooks are categorizable into three types: device-based, reading softwarebased, and web-based $(\mathrm{Gu}, \mathrm{Wu}, \& \mathrm{Xu}$, 2015 : 28). Looking at its characteristics as described above, the Schulz MSA $E$-textbook is in the web-based category. This category E-book is considered as making it easy for the users to use it on the personal computer, laptop, or mobile gadgets. As long as the device is connected to the computer with Windows, IOS, or Android, the program can be accessed easily by the learners. This is different from reading software-based $E$-books in that the material can be opened using installed computer or gadget programs with PDF, CHM, TXT, DOC, ISILO, DEJAVUE, and others. For example, the PDF E-book file can be opened when the Adobe Acrobat has been installed.

The resource designs of the Schulz $E$-textbook represent the characteristics of modern instructional materials inasmuch as they are multi-media and interactive. It is, however, a fact that the minimal number of the audiovisual resources, such as videos that are characteristic of the IT contents of the 4.0 industrial era has forced the learners to be satisfied with text listening and reading. The narrative texts, however, are able to decrease the ability of the reading duration since $E$-materials give more potentials for eye strain on the readers' eyes than printed materials (paper book) do. It is therefore true that, as what happens in Sunan Ampel ISA, students enjoy spending time reading the printed materials and they spend some money buying the paper book besides having the Schulz E-textbook version.

The composition of the Schulz E-textbook contents can be seen as placing Arabic materials for non-Arabic speakers comprehensively presenting Arabic language and contents and spoken and written forms (Al-Qasimi, 1979). The material has also placed Arabic according to the Toemah (1989) descriptions, treating language as a system of sounds, words, and sentences. Although, in the manual, it is stated that the book emphasizes communicative skills (listening, speaking, reading, and writing), it seems to represent itself as an instructional material of the structural approach. 
This can be seen from the practice that every lesson begins with students being asked to understand the sentence patterns (nahwu), word derivation (sharf), and meaning of new vocabulary words. Grammatical structures are presented deductively beginning from explanation of grammar rules followed by examples of use. This is in contrast with materials used by most formal educational institutions in Indonesia, from high school to the university, where presentations begin with examples of use, in the forms of a dialogue (hiwar) and reading (qira'ah) followed then by conclusions of the grammar rules.

An example can be seen in Lesson 17. In the initial phase, explanation is given on the forming of the Arabic conditional sentence by using the word' $i \dot{z} \bar{a}$, 'in, law (if), and habbadā law, kamā law kāna, kamā law 'anna (as if). After that, new words are introduced followed by exercises in the grammatical structure, speaking, reading, and writing. Introduction of the four dialects (Iraq, Syria, Egypt, and Morocco) is presented under the dialogue or reading text. Exercises in dialect use is given in the form of analyses by the teacher and students on the changes that take place in the words or phrases of the Iraqi dialect. The lesson is completed by oral and written assignments on a house map and ended with an $E$-test.

It seems that the visual graphics in the $E$-book may not be suitable for young leaners such as elementary-school students. The children's world is commonly full of fantasies and makes it difficult for them to absorb abstract messages from language. It is, therefore, likely that they will not like the material. Besides the cognitive discrepancies, visually, there are not enough illustrations or pictures in the book. In each lesson, there are only up to 3 pictures found. In terms of the graphical-user principles, the book is not supporting. In this case, the visual semiotics to support pragmatic understanding does not match the children's characteristics. In this case, instead, users are asked to understand the Arabic language and grammar with the support of lists of word translations of new vocabulary and textual semiotics of texts.

Considering that instructional packages are lesson units with series of instructional activities for analyzing and discussing texts (Syamsi, Sari, \& Pujiono, 2000: 83), Schulz MSA E-textbook is suitable for adult learners such as university students or professionals. This is based on the fact that the grammatical levels, themes, and contents of the reading materials, and learning activities and in the book are quite complex, comparable to adults' life frames that are inclined to be abstract. See, for example, the complexities of the syntaxes and language behaviours in the hypotheses of Dale, Roche, \& Duran (2008) and the complex adaptive system of language of Baicchi (2015).

Presentation of grammatical structures in the E-book can be described as attractive, in line with the logical concepts of adults. This interesting presentation of materials can be seen from how the book gives comprehensive explanations on the grammatical rules of modern Arabic while still paying attention to conventional grammatical rules. For example, in 
explaining the use of adjectives, both predictive and attributive functions are presented. The predicative positions (khabar) can be occupied by verbs, verbal nouns, and nominals. Seen from the ways in which dominant descriptive grammars are given along the pages in each lesson, the Schulz E-textbook can be considered as one which is highly structural productive so that it can be used for the purposes of activelinguistic competencies. These competencies are appropriately acceptable and achievable for adult learners.

Seen from the matter of grammatical complexities, Schulz E-book does not use contrastive strategies, but more of addition instead. Presentation of grammar (nahwu and sharf) does not only refer to modern grammatical patterns with all the dialect developments in different countries, but it also considers traditional grammar as in the turats and al-Quran. Besides, use of verses from the Quran, Hadits, and popular Arabic proverbs in headertexts also marks the use of traditional grammar. The E-book does not seem to contrast modern language against colloquial language; it, on the contrary, is present as a modern plus colloquial language.

Compared to other packages of Arabic instructional materials, Schulz MSA E-textbook has many superior aspects. As an instructional material of LAFL, the textbook can be seen as possessing the ideal requirements for a language instructional material since it gives the qualified bases for Arabic active mastery in accordance with standard grammar rules. In addition, the material can be used for autonomous learning since it has been completed with clear interface directions for doing the exercises and preparing for the on-line test.

In relation to the MSA reading text analysis, before the use of discourse analysis, the process begins with comparing between the header text and the contents of the reading text. Semantic comparison is done by looking at the congruence between the contents of the header text and the reading text in each lesson. For example, the header text for Lesson 1 must be coherent with its reading text. However, this does not happen for all lessons. Of the total 24 lessons, only lessons 7 and 12 have the congruence. In lesson 7 , the header text gives the proverb that the best friend is a book; and the reading text is about an international book fair. In Lesson 12, the header text is a quotation from a Hadits that fasting makes one healthy; and the reading text presents an account of Islamic medicine and its history. Therefore, when students open lessons 7 and 12, they will have initial comprehension of the pragmatic contexts that are presented in the visual texts.

On the other hand, the theme of the header text for Lesson 8 is actually agreeable with the theme of the reading text of Lesson 9. In this example, the header text for Lesson 8 mentions a Quran verse that Islam is the most acceptable religion by the side of Allah; meanwhile, its reading text presents something related to education. On the other hand, this theme about religiosity is contained in the reading text of Lesson 9. In fact, there is the inclination for header 
texts to use religious themes. Most of the header texts present a religious aspect. For example, Lessons 1, 2, 3, 4, 8, 9, 19, and $23(33 \%)$ use the diction of Allah while the rest $(67 \%)$ use other religious words such as al-din and al-islam and various values from the Quran, Hadits, or mahfudhat.

Meanwhile, header texts tend to relate to discourses outside the religious aspect. The header texts for Lesson 9 is related to an Islamic theme, Lesson 21 to a source of Islamic teaching, Lesson 8 to Islamic education, Lesson 16 to Islamic economy, Lesson 18 to Islamic organizations, and Lessons 14 and 18 to Islamic artefacts and cultures. The rest are concerned with modern life related to social, political, technological, and environmental matters. The presence of texts that are not coherent is presented in more details below. The first is one with an educational content.

Al-jāmi'ât al-islāmiyyah hiya ihdā aljāmi 'āt al-hadîśah wa lā yadrusu fîhā muwātinū al-baladi fahasb, bal aydan alkaśir min al-țālib al-jawānib min jamī'i buldān al-'ālami taqrīban.

The Islamic university is one of the modern universities in which the students are not only native people but also foreign students from almost all the countries in the world (Lesson 8, page 187).

The text is related to the importance of Islamic education and its institutions. The Indonesian Islamic universities receive much attention not only from Indonesian students but also from foreign students. The Schulz materials mention Islamic universities since Islamic diction takes a strategic role in the development of the Arabic language both in substance and institution. Kairo University in Egypt, for example, becomes a prototype of universities that is originally Asian and not affiliating to the management prototype of European universities.

Looking back at Figure 3, on the content classification of the Schulz MSA materials, it can be seen that there is a big portion of cultural contents in the book. The following is an example of socialcultural contents in the Schulz materials.

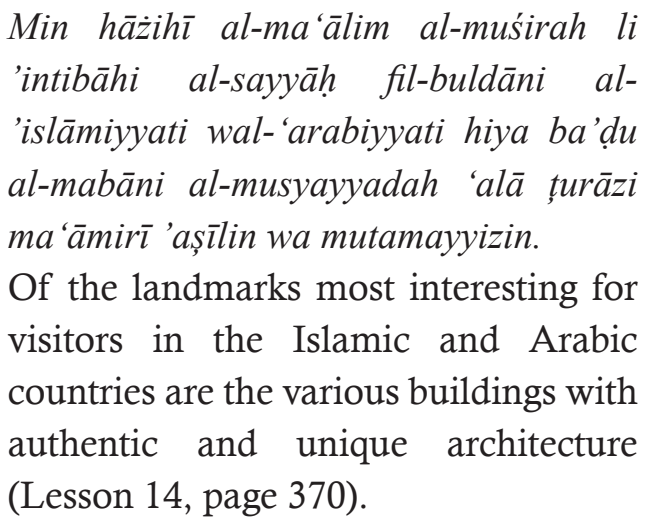

The text tells about a cultural phenomenon where the Arabic language is closely attached to the Arabic and Islamic world. In this case, the architectural styles of Arabic famous buildings have authenticity and uniqueness that attract attention for the tourism sector. The diction 'authentic' and 'Arabic' is used by Schulz to justify the presence of Arabic cultures in the use of the Arabic language. It is understood that the use of Arabic cannot be detached from the history of the Tadmur cultures in Syria, giant buildings to mark the city 
state of Al-Anbat or Petra in Jordan, etc. All these buildings have been destroyed by Roman, Ethiopian, and Persian soldiers leaving out artefacts and remnants of high culture before the birth of Islam. However, Schluz embraces these cultural contents in the text materials using the diction of 'Islam'. Schulz is fully aware that Arabic texts cannot be separated from Islam since the Islamic holy book and much of the religious literature are in Arabic.

In relation to technological discourse, the following quotation is an example of the use of cyber technology in the book.

\begin{tabular}{|c|c|}
\hline eporter & $\begin{array}{l}\text { Wa kayfa yatimmu żälik? Wa hal } \\
\text { hāża min șamimi takhașsuşiki? } \\
\text { 'How is this done? Is this the } \\
\text { core of your expertise?' }\end{array}$ \\
\hline Salma & $\begin{array}{l}\text { Ţab 'an, ajhizat al-ațtibbi al- } \\
\text { hadīśah kulluha mutabițah bil } \\
\text { komputer aw hiya juz 'un minhu. } \\
\text { Wa nahnu nuțawwiru al-baramij } \\
\text { wat-tațbīāt allatī tusayyiru al- } \\
\text { komputirat al-șakhşiyyah wal- } \\
\text { khawādim. } \\
\text { Most certainly, all modern } \\
\text { medical devices are connected } \\
\text { to the computer or part of the } \\
\text { computer and we develop } \\
\text { programs and applications that } \\
\text { run our computer sets or } \\
\text { personal servers (Lesson } 15, \\
\text { page } 401 \text { ). }\end{array}$ \\
\hline
\end{tabular}

The text narrates the development of the cyber culture and technology in the medical world. The choice of the diction is more developed in accordance with the theme. For example, the word khāwädim, whose lexical meaning is 'helper', in the context of technology and modern culture, has narrowed down into computer 'server'. Schulz does not hesitate to use borrowing from foreign languages although similar words have existed in Arabic. For example, alkamputirāt 'komputer' is used in the text despite the existing al-hāsübüt with the same meaning. In this case, the popularity of the diction is regarded as more important than that in the native language with low popularity. The dialogue above also gives a pragmatic signal how Arabic also plays its role in the development of modern civilization and not merely a language for religious matters.

By carrying the concepts and values of modern life in its design, the Schulz MSA E-textbook presents itself as a collective awareness where language is no more a mere heritage textbook, but it has changed its performance in line with the 4.0 industrial era with its social contemporary dynamics based on cyber technology and artificial intelligence. Moreover, now that Arabic is not just a language but an important one in the News Market, it has now become important in the marketing of online languages (thenewsmarket.com). It is therefore fair to say that the contemporary challenges of presenting materials in online formats have been answered accurately by Schulz with the design of his E-edition book.

Meanwhile, in the religious theme, the following is an example.

Maria : Hal al-șawmu wājibun? 'Is fasting an obligation?' 
As'ad : Mabda'iyyan na'am, wa lākin hunāka istiśnā'an, maśalan lil marḍā wasy-syuyūkh wan-nisā'alhawāmil wal-musāfirīn.

'In principle, yes. But there are exemptions, such as for sick persons, very old people, pregnant women, and travellers' (Lesson 9, page 225).

The text is concerned with the obligation of Moslems to carry out fasting. It is interesting that the questioner is acted by Maria (Mary), which is identical with a Catholic name, rather than Mariyam which is populer in the Arabic lexicography. In this case, the text presents role relations among speakers of different religious embracers. This type of role relations, dialogues among embracers of different religions, is rarely found in instructional packages. However, it can be found in Schulz MSA $E$-textbook.

The contexts for the dialogue above can be frequently found in European social interactions where the Moslem community becomes a minority and where there is gender equality that places women as equal to men. In this case, the character Maria (Mary) takes the active role to greet and ask a question to a male listener As'ad. In the Schulz E-textbook, this is not done by accident; but it is done intentionally. The following text presents another example.

Yulia : Al-'ulūm al-țabī'iyyah fil-qur'ān? 'alaysal qur'ānu kitāban dīniyyan khālișan ya 'tamiduhū al-muslimūna dustūran lisy-syarā'i?

'Physics in the Quran? Isn't the Quran is a religious holy book believed by the Moslems to contain religious rules?'
Rasid: Hażā șaḥihh juz'iyyan wa lākinnna al-qur'āna wal-sunnah alnabawiyyah aydan bi āyātin tad' 'ū 'ilā al-tafakkuri fì al-kawni wal-baḥś 'anil-ma'rifah...

Well, partly correct. But, the Qur'an and the Prophet's Sunnah are rich of verses on the orders to do reflection on the universe and search for knowledge. (Lesson 21, page 573 ).

When it is put into close observation, this dialogue has the same characteristics as the one in Lesson 9, page 225, between Maria and As'ad. In this case, the characterYulia asks a question about the Quran to the listener Rasid. In addition to the atmosphere that it is genderfriendly, the dialogue also presents speakers who are a Moslem and a nonMoslem, namely Rasid and Yulia. However, it is an empirical fact that Arabic texts are much characterized by the domination of males over females. In this case, many reading texts in the Schulz E-textbook can be seen as turning the factual phenomenon over. Meanwhile, in term of the contents, the materials tell how Islamic teaching is not merely concerned with religious affairs, but it is also concerned with science development.

In the case of texts that are related to economic and environmental matters, the following quotation can be an example.

Bāta darûriyyan li al-duwal allatī tu'assisu iqtisādaha 'alā tașdīri al-bitrāl 'an tas 'ā li'̄ì̄d badā'il lisaddi hājātiha min al țāqāt fi al-mustaqbali.

It has been a necessity for countries that depend their economy on the oil 
exports to find alternatives for their energy needs in the future (Lesson 11, page 268).

This text shows how Schulz MSA $E$-materials also raise the issues of the importance economic development that is environmentally friendly. In the midst of the hedonistic and consumptive life styles of the Arabs, who are rich because of the oil exploitation, this discussion is important to be presented. This can be regarded as an auto-criticism for the users of the Arabic language and culture as well as a characteristic of modern instructional materials which usually possess a wide selection of language discourse.

In both the critical and general judgements, the Schulz MSA E-textbook can be seen as having fulfilled the hypotheses suggested by Fatima Dar's (2012) Textbook Materials and their Successful Application in the Classroom: Implications for Language Development. Dar states that in developing language education, the designing of the instructional package should fulfill three criteria: (1) global and local contents, (2) authenticity, and (3) adaptation. In the first requirement, foreign language teaching should place a good balance between foreign and local contents. In this case, students are expected to be exposed to foreign cultures without ignoring native cultures. Local cultures are regarded as important. In the learning situations, students are exposed with contrasts between domestic affairs and international affairs.
This is an aspiration for the students to be able to develop their knowledge and cultural backgrounds for their personal identity in the midst of global contexts. It is unfortunate that, conversely, students may experience cultural degradation from being exposed to foreign cultures. It is for this reason that Schulz textbook has included verses and phrases from the Quran, Hadits, and Mahfudhat in early pages to expose the learners to traditional and local cultures and values. The same case applies for the Indonesian contexts since the Indonesian learners are mostly Indonesian Moslems. As for the global contexts, the textbook presents universal contents in the reading texts although these sometimes are in contrast with religious values.

In the second criterion, authenticity, the Shulz E-textbook has taken consideration of how texts should be presented in language that is truly used in real life. In term of the Arabic language, modern Arabic has involved the dialectic value development as an influence among the Arabic countries themselves. For this, the Schulz textbook has integrated the use of the different dialects in the materials. This can be seen as one special characteristic of the book since it facilitates dynamic language learning materials without decreasing the appreciation of traditional texts. A weakness in the introduction of the four dialects is apparent, however, in that no additional explanation is given on the textual characteristics of the use of the dialects. For non-Arabic learners, such as Indonesians, such additional explanation 
is needed. Language is, in one way, representation of cultures; adequate explanation on the our popular Arabic dialects can be used as a symbolic representation of the countries and communities of the Arabic people (Mahadi \& Jafari, 2012).

For the third criterion, material adaptation, instructional materials should be designed such that they can be accepted, absorbed, and understood by the learners. Generally, learners do not readily accept and understand reading texts, especially the ones on global issues. In this case, the instructor plays an important role since he or she can help in bringing the suitability of the text contents with their appropriate contents as protective factors (Mcivor, Napoleon, \& Dickie, 2009) for the balance among the values of the modern language, cultures and religious teachings. All this has been done in the Schulz textbook. The result is that religious texts do not come to be dominant in the textbook since adaptation is done generally for the purpose of linguistic exposure; cultural modernization and linguistic variants are given more prominence. This can be seen within the text materials in the 24 lessons with the contents of life frames of the global cultures presenting the issues of science dynamics, social technology, communication, and transportation.

Uniquely, in learning the language, Indonesian leaners are characterized by backgrounds that tend to be dominated by religious values so that it takes longer for them to be adapted with the $E$-textbook. In this case, the instructors may well consider Petković (2007) research findings that recommend adaptation in the global level should be quickly manifested in the community's daily life, language, and cultures of the local level. In addition, the study by Defina et.al. (2019: 161) on ILFL (Indonesian Language for Foreign Learners) also recommends that learners' perceptions be taken into consideration in developing an instructional material. Therefore, the development of the Schulz MSA E-textbook can be carried out by considering the suitability of the texts based on the geographical zonation such as the continental backgrounds of the learners.

Should the foregoing discussion be sharpened by critical discourse analyses, it can be focused on the inequality of contents among the linguistic, cultural, and religious aspects of the contents in the materials. From the perspectives of Holden (2006) as an articulation of values showing how much language users see the existing cultural realities, the Schulz $E$-textbook can be seen as one that is designed and published by European scholars, Leipsiq University, based more on their cultural realities. This is in line with the study of Ingelehart and Baker (2000) showing that economic development is tied to pervasive cultural changes. Besides, industrialization demands the shift from traditional to rational secular values (Ronald \& Baker, 2000). An implication is the presence of texts that does not match with the cultural contexts of the learners. , muncul beberapa teks yang kurang sesuai dengan konteks budaya pemelajar. The Schulz MSA E-textbook, however, has given 
room to the presence of the rational secular values of the European scholars. This is in agreement with the case of foreign language learning transformation in the Northern Ireland in which language education policies are developed in the contexts of identity conflicts and linguistic inheritence as political issues on a modern language (Wyburd, 2015: 21).

It seems true that the texts in the Schulz MSA E-textbook represent the author's views that the community at large should still follow the hypothesis (Faruqi, 2007) on the mid-century Islamization of Western science as an approach to Islamic holistic values. This hypothesis underlines the presence of religious texts translated more as a subordinate cultural product so that they become not as primary texts, but more as secondary ones. This happens most probably because Arabic is seen more as a culture rather than a value system (Roibin, 2010); or, as what is expressed by Pritchard (in Marzali, 2012: 73), because language is no more than a sociological fact, and not a theological one.

It is interesting how this view is ignored by the Schulz E-textbook by putting in religious verses and proverbs as header texts on every page although they may not always congruent with the corresponding reading texts. Although such quotations are seen only as page decorations, the Schulz e-textbook has sub-consciously placed itself as one that guards the humanistic continuity of the speakers of Arabic since a society without culture is one that has lost their identities
(Anyanwu, 2015:19). The identities of Arabic and religious values can be quickly eroded if religious texts are rarely used. Identities can vanish quickly without the presence of an active language (Dorais, 1995: 304).

One shortcoming of the instructional package is the absence of the targeted basic competence at the beginning of each lesson. Learners or users are directed immediately to read the manual and list of contents whereas the materials and exercises are recommended not to be done in a sequential order. On a positive point, the book presents themes that are recent and up-to-date, practical grammar with varied stylistics, varied texts, and dynamic and enjoyable activities. On a negative point, listening to and retelling aural texts of the four dialects and understanding of modern vocabulary words tend to be slow. However, the E-book prioritizes grammar, but not ignoring notional and situational approaches or other aspects in selecting instructional materials; it is multidimentional.

\section{CONCLUSION}

The design of the Schulz MSA e-textbook has placed the textbook as a modern instructional package for Arabic as an international language. The webbased material is expected to support learning in the disruptive manner which becomes a characteristic of instruction of the 4.0 industrial era. It is only that multimedia-based resources, such as videos, are note completely adequate. In presenting the interfaces, the materials have been arranged in accordance with 
the manuals and use of the standard language (fusha) without ignoring the variant differences in the four dialects of Egypt, Syria, Morocco, and Iraq. In terms of vocabulary, the material is adequately representative in accommodating various international vocabulary entries. Words and phrases are presented in the reading texts within the 24 lesson units of the package. Although religious texts do not occupy the highest portion of the book, quotations in the forms of verses and proverbs from the Quran, Hadits, and mahfudhat are abound throughout the pages.

Discourse pieces in the Schulz materials are complete and comprehensive covering a large variety of themes in education, social affairs, economy, culture, politics, religion, environment, and technology. It is interesting to note that, although there are many religious texts in the materials, the Arabic language in the texts looks as more of sociocultural facts rather than theological facts. The religious contents in the materials seem to be dominated more by rational secular systems of life rather than by value systems. The same phenomena happen with texts that come from the Quran so that, although there are a lot of header texts in the materials, their existence is not much tied to the reading texts in the lesson units; these are used mostly as content exposure.

One recommendation coming out of the findings of the study is for the instructors to be able to bridge the gap in the materials by way of other aspects of instruction considering that the learners, most specifically Indonesians, tend to look at Arabic as not merely a cultural product; but it, more than that, is regarded as a language of the holy book rich in life values. At any rate, the Schulz MSA e-textbook has been in existence as an inspirative Arabic instructional material package of the $21^{\text {st }}$ century; its presence needs to be appreciated and such creative efforts need to be supported in the future in furthering the development of the teaching of Arabic as a foreign language.

\section{ACKNOWLEDGEMENTS}

Gratitude is bestowed to Prof. Dr. Eckehard Schulz who has directly given the researcher training in the use of the MSA E-texbook at Leipziq University in 2015. Statements of appreciation are also dedicated to Prof. H. Masdar Hilmy, S. Ag., M.A, Ph.D., Rector of Sunan Ampel ISU, Prof. Dr. H. Sahid HM, M.Ag., M.H., Director of the Research and Community Services Centre of Sunan Ampel ISU, and Prof. Abdul Kadir Riyadi, Ph.D., Director of the Language Services Centre of Sunan Ampel ISU for giving the opportunity to the researcher to use the Schulz MSA E-textbook in the Arabic classes, since 2017, and facilitating the study.

\section{REFERENCES}

Abdelali, A. (2004). Localization in Modern Standard Arabic. Journal of The American Society for Information Science and Technology, 55(1), 23-28. https://doi.org/10.1002/asi.10340. 
Aljasser, F. \& Vitevitch, MS. (2018). A Web-based interface to calculate phonotactic probability for words and nonwords in Modern Standard Arabic. Behavior Research Methods. 50(1), 313-322. https://doi. org/10.3758/s13428-017-0872-z.

AlQasimi, AM. (1979) Ittijâhât Hadîtsah fì Ta 'lìm al-" Arabiyyah li alNâthiqîn bi al-Lughah al-Ukhrâ, Riyadh: 'Imadah Syu'un alMaktabah Jami'ah Riyadh. https:// www.goodreads.com/book / show/47325172.

Anyanwu, C. (2015). Traditional Values Versus Modernity: Towards A Resolution Of The Dilemma Of Culture Conflict In African society. International Journal African Society, Cultures and Traditions, 3(4), 12-21. https://doi.org/10.1017/ CBO9781107415324.004.

Baicchi, A. (2015). Complex Adaptive Systems: The Case of Language. Book: Construction Learning as a Complex Adaptive System, Springer Briefs in Education, 20-21. https:// doi.org/10.1007/978-3-319-182698_2.

Behnke, Y. (2018). Book Chapter: Textbook Effects and Efficacy. The Palgrave Handbook of Textbook Studies, 383-397. https://doi.org/https:// doi.org/10.1057/978-1-137-531421_28.

Defina, R., Ridwan, S. (2019). Assessment of Students on BIPA Teaching Materials Special Materials of Agriculture. Litera: Jurnal Penelitian Bahasa, Sastra dan Pengajarannya.
18(1), 15-163. http://dx.doi. org/10.21831/ltr.v18i1.15613.

Diab M., Hacioglu K., Jurafsky D. (2007) Automatic Processing of Modern Standard Arabic Text. In: Soudi A., Bosch A.., Neumann G. (Eds) Arabic Computational Morphology. Text, Speech and Language Technology, vol 38. Springer, Dordrecht, 159-179. https: / / doi.org/10.1007/978-14020-6046-5_9.

Dorais, L.-J. (1995). Language, Culture and Identity: Some Inuit Examples. Canadian Journal of Native Studies, 15(2), 293-308. http://www3. brandonu.ca/cjns/15.2/dorais.pdf.

Droua-Hamdani, G., \& Selouani, S.A., \& Boudraa, M. (2012). Speakerindependent ASR for Modern Standard Arabic: Effect of Regional Accents. International Journal of Speech Technology. 15(4). https://doi. org/10.1007/s10772-012-9146-4

Ediyani, M. (2016). Analisis Materi Pembelajaran Bahasa Arab Pada Buku Al-Lughah Al-'Arabiyah AlMu'âshirah dengan Pendekatan Asas Pengembangan Materi, AlMaharata: Jurusan Pendidikan Bahasa Arab. 2(1), 119-144, https://doi. o r g / 10 . $1444421 /$ almahara.2016.021-06.

Fairclough, N. (2003). Book Chapter: Technologisation of discourse, In: Carmen Rosa Caldas-Coulthard and Malcolm Coulthard (Eds), Texts and Practices: Readings in Critical Discourse Analysis, $\quad 71-83 . \quad \mathrm{https}$ ///www. academia.edu/35954722/ 
Carmen_Rosa_Caldas-Coulthard_ Malcolm_Coulthard_Text_and_ Pratice_reading_ in_critical_ discourse_analysis_.

Faruqi, Y. M. (2007). Islamic View Of Nature And Values : Could These be The Answer to Building Bridges Between Modern Science and Islamic Science. International Education Journal, 8(2), 461-469. https://files.eric.ed.gov/fulltext/ EJ834281.pdf.

Fatima, D. (2012). Textbook Materials and Their Successful Application in the Classroom: Implications for Language Development. Journal of Educational and Instructional Studies in the World, 2(4), 109-114. http:// www.wjeis.org/File Upload/ ds217232/File/13.dar.pdf.

Gu, X., Wu, B., \& Xu, X. (2015). Design, Development, and Learning in E-Textbooks: What We Learned and Where We are Going. Journal of Computers in Education, 2(1), 25-41. https://doi.org/10.1007/s40692014-0023-9.

Holden, J. (2006). Cultural Policy is a Closed Conversation Among Experts . What Culture Needs is a Democratic Mandate from the Public. London: Demos. https://studylib.net/ doc/13099893/.

Jaeni, M., (2015). Thariqatu Ta'lim alLughah al-'Arabyyah 'Inda alMustasuriqin: Dirasah Tahliliyah li Kitab al-Lughah al-'Arabiyyah alMu'ashirah Lil Ustdaz Eckehard Schulz, Hikmatuna: Journal for
Integrative Islamic Studies, 1 (2), 211-244. http://e-journal. iainpekalongan.ac.id/index.php/ hikmatuna/article/view/935/1088.

Loukam, M., Hammouche, D., Mezzoudj, F., \& Belkredim. FZ. (2019). Keyphrase Extraction from Modern Standard Arabic Texts Based on Association Rules. In: Smaïli K. (eds), Arabic Language Processing: From Theory to Practice. ICALP 2019. Communications in Computer and Information Science, vol 1108. https://doi.org/10.1007/9783-030-32959-4_15.

Mahadi, T. S. T., \& Jafari, S. M. (2012). Language and Culture. International Journal of Humanities and Social Science, 2(17), 230-235. https:// www.ijhssnet.com/journals/Vol_2_ No_17_September_2012/24.pdf.

Marzali, A. (2012). Agama dan Kebudayaan. UMBARA : Indonesian Journal of Anthropology, 1(1), 57-75. https://doi.org/10.24198/umbara. v1i1.9604.

Masyhud, F. (2017). Tadzawwuq AlLahajât Al-'Arabiyyah 'Abr AlTa'lîm Al-Iliktrûnî : Tadrîs Kitâb Al'Arabiyyah Al-Mu'âshirah Namûdzajan. Arabi : Journal of Arabic Studies , 2(2), http://dx.doi. org/10.24865/ajas.v2i2.59.

Mcivor, O., Napoleon, A., \& Dickie, K. M. (2009). Language and Culture as Protective Factors for At-Risk Communities. Journal De La Santé Autochtone, 19-20. http://www. ecdip.org/docs/pdf/McIvor_ 
Napoleon\%202009.pdf.

Nassiri, N., Lakhouaja, A., \& CavalliSforza, V. (2018). Arabic Readability Assessment for Foreign Language Learners. https://doi.org/10.1007/ 978-3-319-91947-8 49

Pepin, B., Gueudet, G., \& Trouche, L. (2013). Investigating Textbooks As Crucial Interfaces Between Culture, Policy And Teacher Curricular Practice: Two Contrasted Case Studies In France And. ZDM Mathematics Education, 45(5), 685698. https://doi.org/10.1007/ s11858-013-0526-2.

Petković, J. (2007). Traditional Values And Modernization Challenges In Forming Urban And Rural Culture. Facta Universitatis. Series: Philosophy, Sociology and Psychology, 6(1), 23-39. http://facta.junis.ni.ac.rs/pas/ pas2007/pas2007-02nn.pdf

Pransiska, T. (2018). Buku Teks Al-Lughah Al- ' Arabiyah Al-Mu' Āshirah Bagi Penutur Non Arab: Desain , Kontruksi Dan Implementasi. AlFikra: Jurnal Ilmiah Keislaman, 17(1), 1-20. http://dx.doi.org/10.1234/ af.v17i1.5123.

Purwanta, H. (2013). Evaluasi Isi Buku Teks Pelajaran Sejarah Pada Masa Orde Baru. Jurnal Cakrawala Pendidikan, (3), 424-440. https:// doi.org/10.21831/cp.v0i3.1551.

Richards, J. C. (2015). Materials Design in Language Teacher Education: An Example from Southeast Asia. International Perspectives on English Language Teacher Education, 90-106. https://doi.org/10.1057/ 9781137440068_6.

Roibin. (2010). Agama dan Budaya : Relasi Konfrontatif Atau Kompromistik? JURISDICTIE Jurnal Hukum dan Syariah, 1(1), 1-12. http://dx.doi. org/10.18860/j.v0i0.1590.

Ronald, I., \& Baker, W. E. (2000). Modernization, Cultural Change, and the Persistence of Traditional Values. American Sociological Review, 65(1). https://doi.org/10.2307/2657288.

Schuh, K. L., Russell, J., \& Horne, S. Van. (2018). E-textbook as Object and Mediator: Interactions Between Instructor and Student Activity Systems. Journal of Computing in Higher Education, 30 (1). https://doi. org/10.1007/s12528-018-9174-4.

Schulz, E. (2017). Modern Standard Arabic. Jerman: Universitas Leipzig. https://modern-standard-arabic. net/id/.

Syahra, R. (2003). Modal Sosial : Konsep dan Aplikasi. Jurnal Masyarakat dan Budaya, 5(1), 1-22. http://jmb.lipi. go.id/index.php/jmb/article/ view/256/234.

Syamsi, K., Sari, E. S., \& Pujiono, S. (2000). Pengembangan Model Buku Ajar Membaca Berdasarkan Pendekatan Proses Bagi Siswa SMP. Cakrawala Pendidikan: JurnalIlmu Pendidikan, 1, 82-90. https://doi. org/10.21831/cp.v5i1.1262.

Taufikurrahman, R. (2015). Bahasa Arab Baku dan Modern / Al-'Arabiyah Al-Mu'ashirah (Sebuah Alternatif). OKARA: Jurnal Bahasa dan Sastra. 
9(2). http://dx.doi.org/10.19105/ ojbs.v9i2.672.

Toemah, Roushdy A. (1989). Ta'lim al'Arabiyyah li Ghayrin Nathiqin biha. ISESCO. https://ci.nii.ac.jp/ncid/ BA73103256?1=en.

Van Dijk, T. A. (2006). Ideology and discourse analysis. Journal of Political Ideologies, 11(2), 115-140. https://doi. org/10.1080/13569310600687908.
Wyburd, J. (2015). Case Study: Language learning as transformative - the experience of a Cambridge medical student, The Value of Languages: Ideas for a UK Strategy for languages. A Report of a Workshop Held in Cambridge in October, Cambridge Public Policy SRI, 21. https://www.publicpolicy.cam.ac. uk/pdf/value-of-languages. 